\title{
MODEL PENDIDIKAN KESETARAAN PAKET A SETARA SD/MI MATA PELAJARAN PPKN
}

\author{
10.34005/akademika.v8i02.500
}

\author{
Nurhafni \\ nurhafni1965@gimail.com \\ BP PAUD dan Dikmas ACEH
}

\author{
Khasanah \\ Khasanahrcl.mtp@uia.ac.id \\ Universitas Islam As-Syafi'iyah Jakarta
}

\begin{abstract}
Abstrac: Exploration studies conducted in reality show that the implementation of equality education at the Center for Community Learning Activities (PKBM) is still not in accordance with the demands of the curriculum and National Standards for Early Childhood Education and Community Education. The purpose of this study are: 1) to find out how the steps in the preparation of equality education modules in the PPKn Package A equivalent to $S D$ / MI, 2) Testing the effectiveness of learning by using modules in the learning process. 3) Test the validity and reliability of equality education module products in PPKn Package A courses equivalent to SD / MI. The target in this study was grade VI students at PKBM Putri Gina which consisted of one class with 15 learning residents. This study uses a sampling technique is purposive sampling that is deliberate sampling in accordance with the requirements of the composition of sample members based on the type of treatment. Based on the results of the. This is also supported by the preparation of modules that are independent and contextual so as to facilitate citizens to learn packages that have limited, time to attend teaching and learning activities can continue to follow module-based learning independently. Discussion, it was concluded that the model A education model is equivalent to SD/MI PPKn subjects. After testing, learning by using the equivalency module A package SD / MI PPKn subjects have effectiveness in the learning process
\end{abstract}

\section{Keyword : Model, Equality Education, Package A Equivalent SD / MI}

\begin{abstract}
Abstrak: Studi eksplorasi yang dilakukan realitas menunjukkan bahwa pelaksanaan pendidikan kesetaraan pada Pusat Kegiatan Belajar Masyarakat (PKBM) masih belum sesuai dengan tuntutan kurikulum dan Standar Nasional Pendidikan Anak Usia Dini dan Pendidikan Masyarakat. Tujuan penelitian ini adalah : 1) mengetahuai bagaimanakah langkah penyusunan modul pendidikan kesetaraan Mata Pelajaran PPKn Paket A setara $\mathrm{SD} / \mathrm{MI}, 2)$ Pengujian efektifitas pembelajaran dengan menggunakan modul dalam proses pembelajaran. 3) Menguji validitas dan reabilitas dari produk modul pendidikan kesetaraan Mata Pelajaran PPKn Paket A setara SD/MI.Target pada penelitian ini adalah peserta didik kelas VI di PKBM Putri Gina yang terdiri dari satu kelas dengan jumlah warga belajar 15 orang. Penelitian ini menggunakan tehnik pengambilan sampel adalah purposive sampling yaitu pengambilan sampel secara sengaja sesuai dengan pesyaratan komposisi anggota sampel berdasarkan jenis pelakuan. Berdasarkan hasil pembahasan maka disimpulkan model pendidikan paket A setara SD/MI mata pelajaran PPKn. Setelah dilakanakan pengujian, pembelajaran dengan menggunakan modul kesetaraan paket $A$ SD/MI mata pelajaran PPKn memiliki keefektifan dalam proses pembelajaran.
\end{abstract}

Kata Kunci : Model, Pendidikan Kesetaraan, Paket A Setara SD/MI 


\section{PENDAHULUAN}

Salah satu tujuan Negara Kesatuan Republik Indonesia sebagaimana termaktub dalam Alenia Keempat Pembukaan Undang Undang Dasar Republik Indonesia Tahun 1945 adalah untuk mencerdaskan kehidupan bangsa karena disadari bahwa kemajuan suatu bangsa sangat ditentukan dari tingkat pendidikan warganegaranya. Oleh karena itu, peningkatan kualitas warganegara ini menjadi tanggungjawab dari negara. Hal ini sebagaimana dimanatkan oleh pasal 31 Undang Undang Dasar Negara Republik Indonesia Tahun 1945 bahwa:

1. Setiap warganegara berhak mendapatkan pendidikan.

2. Setiap warganegara wajib mengikuti pendidikan dasar dan pemerintah wajib membiayainya.

3. Pemerintah mengusahakan dan menyelenggarakan satu sistem pendidikan nasional yang meningkatkan keimanan dan ketakwaan serta akhlak mulia dalam rangka mencerdaskan kehidupan bangsa yang diatur dengan undang- undang.

4. Pemerintah memprioritaskan anggaran pendidikan sekurangkurangnya dua puluh persen dari Anggaran Pendapatan dan Belanja Negara serta dari Anggaran Pendapatan dan Belanja Daerah untuk memenuhi kebutuhan penyelenggaraan pendidikan nasional.

Dalam hal ini, sistem pendidikan nasional yang diselenggarakan oleh pemerintah harus mampu mewujudkan pemerataan pendidikan kepada semua warganegara.Hal ini diperlukan agar terciptanya peningkatan kualitas warganegara yang tetap eksis di era global. Pemerataan kesempatan warganegara untuk mengenyam dunia pendidikan tidak hanya didominasi oleh pendidikan pada jalur formal semata, akan tetapi juga melaui jalur informal dan non formal yang dikenal dengan Tri Pusat Pendidikan yaitu keluarga, sekolah, dan masyarakat.

Pasal 1 ayat (12) Undang Undang Nomor 20 Tahun 2003 tentang Sistem Pendidikan Nasional menjelaskan bahwa: "Pendidikan nonformal adalah jalur pendidikan diluar pendidikan formal yang dapat dilaksanakan secara terstruktur dan berjenjang". Selanjutnya, pendidikan nasional diselenggarakan dalam rangka mencapai tidak hanya Kompetensi tiga dan empat, akan tetapi yang lebih penting lagi adalah memperkuat jati diri bangsa sebagaimana isi dari kompetensi satu dan dua pada Kurikulum 2013. Oleh karena itu, upaya memperkuat jati diri bangsa melalui pendidikan nasional ini sebagaimana diamanatkan oleh pasal 3 Undang Undang Nomor 20 Tahun 2003 tentang Sistem Pendidikan Nasional menyatakan 
Pendidikan nasional berfungsi mengembangkan kemampuan dan membentuk watak serta peradaban bangsa yang bermartabat dalam rangka mencerdaskan kehidupan bangsa, bertujuan untuk berkembangnya potensi peserta didik agarmenjadi manusia yang beriman dan bertakwa kepada Tuhan Yang Maha Esa, berakhlak mulia, sehat, berilmu, cakap, kreatif, mandiri, dan menjadi warga negara yang demokratis serta bertanggung jawab

Melaksanakan amanat ini, maka pemerintah menyelenggarakan pendidikan kesetaraan baik paket $\mathrm{A}, \mathrm{B}, \mathrm{C}$, maupun pendidikan keluarga. Penyelenggaraan pendidikan kesetaraan ini dipercayakan kepada suatu badan resmi pemerintah, yaitu Balai Pengembangan Pendidikan Anak Usia Dini dan Pendidikan Masyarakat (BP-PAUD dan DIKMAS). Selanjutnya, secara operasional pelaksanaannya diberikan kepada lembaga pendidikan masyarakat, yaitu Pusat Kegiatan Belajar Masyarakat (PKBM).

Pelaksanaan pendidikan kesetaraan ini diupayakan dapat memenuhi kebutuhan masyarakat, fleksibel dalam penyelenggaraannya, praktis materi pembelajarannya, serta dapat disesuaikan waktu dan tempat pelaksanaannya sesuai dengan kondisi warga belajar. Namun demikian, berdasarkan studi eksplorasi yang dilakukan realitas menunjukkan bahwa pelaksanaan pendidikan kesetaraan pada Pusat Kegiatan Belajar Masyarakat (PKBM) masih belum sesuai dengan tuntutan kurikulum dan Standar Nasional Pendidikan Pendidikan Anak Usia Dini dan Pendidikan Masyarakat. Dimana, hasil studi pendahuluan pada satuinstitusi penyelenggara pendidikan kesetaraan Paket $A$ di Kabupaten Aceh Besar masih terdapat banyak kelemahan dan belum sesuai dengan delapan Standar Nasional Pendidikan. Kondisi tersebut seperti terkait dengan sarana dan prasarana yang tidak representatif, tidak tersedianya alat dan bahan yang dapat menunjang proses belajar mengajar, tidak adanya media pembelajaran, tidak tersedianya bahan ajar yang dapat dijadikan sumber belajar bagi warga belajar, dan kompetensi tutor yang kurang mampu dibidangnya.

Dengan demikian, dari berbagai permasalahan yang ditemukan melalui studi pendahuluan ini menurut peneliti yang paling mendesak harus tersedia adalah hal- hal yang dapat menunjang pencapaian Standar Isi dan Standar Proses seperti model pembelajaran dalam bentuk bahan ajar.Oleh karena itu, studi ini memberikan prioritas penyusunan model khususnya pada pembelajaran Pendidikan Pancasila dan Kewarganegaraan (PPKn) yang dapat digunakan sebagai sumber belajar baik oleh tutor maupun warga belajar. Penyusunan bahan ajar berupa modul yang dapat digunakan oleh tutor dan warga belajar diharapkan memudahkan dalam proses kegiatan belajar mengajar. Modul yang ditulis bersifat mandiri sehingga dapat memudahkan para warga belajar yang tidak memungkinkan untuk bertatap muka dengan tutor dapat 
menggunakan modul ini sehingga kegiatan belajar mengajar tetap berlangsung.

\section{Pendidikan Kesetaraan}

Pendidikan kesetaraan merupakan bagian dari pendidikan nonformal yang memberikan layanan pendidikan Program Paket A setara SD/MI, Program Paket B setara SMP/MTs dan Program Paket C setara SMA/MA, dengan memberikan penekanan pada peningkatan kemampuan ilmu pengetahuan, keterampilan, pengembangan sikap kepribadian kepada peserta didik (Kintamani, 2012:67).

Penyelenggaraan pendidikan kesetaraan lebih diperuntukkan bagi warga belajar yang putus sekolah atau tidak pernah bersekolah.Tujuan utama dari penyelenggaran sistem pendidikan ini adalah untuk meningkatkan taraf hidup dan kehidupan warga belajar. Di era globalisasi, peluang untuk memiliki pertumbuhan ekonomi yang tinggi dan berkelanjutan dari suatu negara akan semakin besar apabila didukung oleh ketersediaan Sumber Daya Manusia (SDM) yang memiliki kompetensi:

1) Pengetahuan dan kemampuan dasar untuk menyesuaikan diri dengan tuntutan dan dinamika pembangunan yang tengah berlangsung. 2) Karakter yang unggul, beriman, dan bertakwa kepada Tuhan Yang Maha Esa. 3) Jenjang pendidikan yang semakin tinggi. 4) Keterampilan keahlian yang berlatarbelakang ilmu pengetahuan dan teknologi (iptek). 5) Kemampuan untuk menghasilkan produk- produk yang unggul, baik dari kualitas maupun harga, sehingga mampu bersaing dengan produk- produk lainnya di pasar global (Suyanto, 2010: 3).

Dari pendapat di atas dapat disimpulkan bahwa upaya peningkatan taraf hidup dan kehidupan warganegara sebagaimana amanat konstitusi tidak terlepas dari aspek pendidikan dan kompetensi. Penyelenggaraan pendidikan nasional tidak terlepas dari partisipasi masyarakat karena mereka tidak hanya menjadi obyek, akan tetapi dan lebih diutamakan adalah masyarakat harus mampu menjadi subyek pendidikan. Oleh karena itu, diperlukan aktualisasi pendidikan nasional yang baru dengan prinsip- prinsip: (1) Partisipasi masyarakat di dalam mengelola pendidikan (community based education), (2) Demokratisasi proses pendidikan, (3) Sumber dayapendidikan yang profesional, (4) Sumber daya penunjang yang memadai, dan (5) Membangun pendidikan yang berorientasi pada kualitas individu berbasis karakter (H.A.R. Tilar, 2000:19).

Dalam hal ini, diperlukan adanya kompetensi tutor yang menguasai profesionalisme keguruan dan ketersediaan sarana dan prasarana yang dapat menunjang proses pembelajaran, terutama bahan ajar bagi warga belajar. Pendidikan nonformal bertujuan untuk pengentasan kebutaaksaraan, keterbelakangan, dan sekaligus kemiskinan warganegara.

Pendidikan nonformal yang diselenggarakan oleh masyarakat sebagai bentuk partisipasi masyarakat terhadap pelaksanaan pendidikan 
nasional. Hal ini sebagaimana dijelaskan lebih lanjut dalam pasal 55 Undang Undang Nomor 20 Tahun 2003, menyatakan

1. Masyarakat berhak menyelenggarakan pendidikan berbasis masyarakat pada pendidikan formal dan nonformal sesuai dengan kekhasan agama, lingkungan sosial, dan budaya untuk kepentingan masyarakat. 2) Penyelenggara pendidikan berbasis masyarakat mengembangkan dan melaksanakan kurikulum dan evaluasi pendidikan, serta manajemen dan pendanaannya sesuai dengan standar nasional pendidikan. 3) Dana penyelenggaraan pendidikan berbasis masyarakat dapat bersumber dari penyelenggara, masyarakat, Pemerintah, pemerintah daerah dan/atau sumber lain yang tidak bertentangan dengan peraturan perundang-undangan yang berlaku.

Pendidikan nonformal dapat dikatakan juga sebagai pendidikan kecakapan hidup (life skills) dengan memberikan kemapuan dasar yang fungsional kepada warga belajar seperti keterampilan membaca, menulis, dan berhitung yang dapat diperoleh melalui pendidikan kesetaraan. Untuk mendukung pencapaian ketiga kompetensi dasar ini sangat ditentukan antara lain oleh metode pembelajaran yang diterapkan, tempat belajar yang digunakan, dan suasana belajar yang diwarnai situasi demokratis (pengembangan rasa percaya diri dan saling menghargai) dari pada instruktif dengan pendekatan satu arah (one way oriented) (Anwar, 2004:56).

Pendidikan nonformal lebih pada upaya menciptakan jiwa kemandirian pada warga belajar.Kemandirian sebagai kepribadian atau sikap mental yang harus dimiliki oleh setiap orang yang didalamnya terkandung unsur-unsur dengan watak-watak yang ada di dalamnya perlu dikembangkan agar tumbuh menyatu dalam setiap gerak kehidupan manusia.Asumsi tersebut menunjukkan bahwa kemandirian dapat menentukan sikap dan perilaku seseorang menuju kearah wiraswastawan.Pada konteks dunia kerja mandiri atau kemandirian muncul seiring dengan berkembangnya orientasi kerja, yang mengarah pada sikap wirausaha/wiraswasta (Kamil, 2007:45).

Namun demikian, kemandirian warga belajar ini dipengaruhi oleh berbagai faktor baik internal maupun eksternal.Munadi (Rusman, 2012:124) menyatakan bahwa, "Faktor- faktor yang mempengaruhi hasil belajar meliputi faktor internal yang meliputi fisiologis (kondisi kesehatan dan jasmani), dan psikologis (IQ, bakat, minat, motivasi, dan daya nalar).Faktor eksternal yang meliputi lingkungan (fisik dan sosial), dan istrumental (kurikulum, komponen, sarana dan guru)."

Penyelenggaraan pendidikan nonformal menerapkan strategi pendidikan orang dewasa (andragogi). Pendidikan dewasa adalah suatu proses yang menumbuhkan keinginan untuk bertanya dan belajar secara berkelanjutan sepanjang hidup. Bagi orang dewasa belajar berhubungan dengan bagaimana mengarahkan diri sendiri untuk bertanya dan mencari jawabannya (Pannen dalam Supriantono, 2008).

Proses pembelajaran orang dewasa akan berlangsung jika dia terlibat langsung, idenya dihargai dan materi ajar sangat dibutuhkannya 
atau berkaitan dengan profesinya serta sesuatu yang baru bagi dirinya. Permasalahan perilaku yang sering timbul dalam program pendidikan orang dewasa yaitu mendapat hal baru, timbul ketidaksesuaian (bosan), teori yang muluk (sulit dipraktikkan), resep/petunjuk baru (mandiri), tidak spesifik dan sulit menerima perubahan (Yusnadi, 2004:24).

Proses belajar bagi peserta pendidikan kesetaraan memerlukan kehadiran orang lain yang mampu berperan sebagai pembimbing belajar bukan cenderung digurui, orang dewasa cenderung ingin belajar bukan berguru. Orang dewasa tumbuh sebagai pribadi dan memiliki kematangan konsep diri, mengalami perubahan psikologis dan ketergantungan yang terjadi pada masa kecil menjadi kemandirian untuk mengarahkan diri sendiri, sehingga proses pembelajaran orang dewasa harus memperhatikan karakteristik orang dewasa. Untuk lebih jelasnya di mari kita perhatian bagaiamanakah pembelajaran andragogi dan Pedagogi, terlihat dalam tabel 1 berikut :

Tabel 1. Pembelajaran Andragogi dan Pedagogi

\begin{tabular}{|c|c|c|}
\hline NO & PEDAGOGI & ANDRAGOGI \\
\hline 1 & $\begin{array}{l}\text { Konsep diri: } \\
\text { a. Anak ialah pribadi yang } \\
\text { tergantung. } \\
\text { b. Hubungan pelajar dengan pengajar } \\
\text { merupakan hubungan yang bersifat } \\
\text { pengarahan. }\end{array}$ & $\begin{array}{l}\text { a. Pelajar bukan pribadi yang } \\
\text { tergantung, tapi pribadi yang telah } \\
\text { masak secara psikologis/ pribadi } \\
\text { yang mandiri. } \\
\text { b. Hubungan pelajar dengan pengajar } \\
\text { merupakan hubungan saling } \\
\text { membantu vana timbal balik. }\end{array}$ \\
\hline 2 & $\begin{array}{l}\text { Pengalaman: } \\
\text { Pengalaman pelajar sangat } \\
\text { terbatas, karena itu dinilai kecil } \\
\text { dalam proses pendidikan }\end{array}$ & $\begin{array}{l}\text { Pengalaman pelajar orang dewasa } \\
\text { dinilai sebagai sumber belajar yang } \\
\text { berkembang }\end{array}$ \\
\hline 3 & $\begin{array}{l}\text { Pesiapan belajar: } \\
\text { Guru menentukan apa yang akan } \\
\text { dipelajari, bagaimana dan kapan } \\
\text { belajar }\end{array}$ & $\begin{array}{l}\text { Pelajar menentukan apa yang mereka } \\
\text { perlu pelajari berdasarkan pada } \\
\text { persepsi mereka sendiri terhadap } \\
\text { tuntutan situasi sosial mereka }\end{array}$ \\
\hline 4 & $\begin{array}{l}\text { Orientasi terhadap belajar: } \\
\text { a. Anak-anak cenderung } \\
\text { mempunyai perspektif untuk } \\
\text { menunda aplikasi apa yang ia } \\
\text { pelajari (digunakan di masa yang } \\
\text { akan datang) } \\
\text { b. Pendekatannya "berpusat } \\
\text { kepada mata pelajaran" (subject } \\
\text { centered) }\end{array}$ & $\begin{array}{l}\text { a. Pelajar cenderung mempunyai } \\
\text { perspektif untuk kecepatannya } \\
\text { mengaplikasikan apa yang mereka } \\
\text { pelajari } \\
\text { b. Pendekatannya "berpusat kepada } \\
\text { masalah" (problem centered) }\end{array}$ \\
\hline
\end{tabular}

(Sumber: Knowles dalam (Diklat Fungsional Penggerak Swadaya Masyarakat, Balitbang Diklat Informasi, Kementerian Daerah Tertinggal dan Transmigrasi, 2015)

Penyelenggaraan program pendidikan kesetaraan untuk memberikan kesempatan belajar kepada masyarakat yang putus sekolah dalam rangka upaya meningkatkan pengetahuan dan keterampilan mereka sebagai bekal dalam menjalani hidup dan kehidupannya.Dalam 
hal ini, secara khusus tujuan diselenggarakannya program pendidikan kesetaraan adalah sebagai berikut:

1) Meningkatkan pengetahuan warga belajar untuk mengembangkan diri sejalan dengan perkembangan ilmu pengetahuan, teknologi dan dunia kerja.2) Meningkatkan kemampuan sikap dan prilaku warga belajar sebagai individu dan sebagai anggota masyarakat dalam mengadakan hubungan timbal balik dengan lingkungan sosial, ekonomi dan alam sekitarnya.3) Meningkatkan pengetahuan keterampilan dan kemampuan warga belajar untuk bekerja, usaha mandiri, serta memberikan peluang bagi yang memenuhi persyaratan dan ketentuan untuk melanjutkan pendidikan pada jenjang yang lebih tinggi (Nasdianto S, 2006: 2).

Pembentukan nilai-nilai karakter dalam mengatasi dampak globalisasi, tidak cukup hanya dengan memberikan kompetensi akademis saja, akan tetapi yang tidak kalah pentingnya adalah penanaman nilainilai karakter atau akhlak yang baik kepada peserta didik. Permasalahan tersebut membutuhkan renungan, sehingga dirasakan perlunya paradigma baru berkaitan dengan pendidikan.Akhir- akhir ini banyak hal yang patut menjadi bahan renungan mendalam, misalnya masalah akhlak atau karakter lulusan, kesesuaian lulusan dengan lapangan kerja (link and macht), dan masalah nasionalisme di tengah era globalisasi.

Dengan demikian, diperlukan pendidikan yang berkaitan dengan pembinaan budi pekerti warga belajar.Pembinaan budi pekerti warga belajar ini telah diatur lebih lanjut oleh pemerintah. Pendidikan budi pekerti bertujuan untuk:

1. Menjadikan sekolah sebagai taman belajar yang menyenangkan bagi siswa, guru, dan tenaga kependidikan. 2)Menumbuhkembangkan kebiasaan yang baik sebagai bentuk pendidikan karakter sejak di keluarga, sekolah, dan masyarakat. 3) Menjadikan pendidikan sebagai gerakan yang melibatkan pemerintah, pemerintah daerah,masyarakat, dan keluarga. 4) Menumbuhkembangkan lingkungan dan budaya belajar yang serasi antara keluarga, sekolah, dan masyarakat (Pasal 2 Peraturan Pemerintah Nomor 23 Tahun 2015 tentang Penumbuhan Budi Pekerti).

Pembudayaan budi pekerti dilakksanakan berdasarkan pada pertimbangan bahwa masih terabaikannya implementasi nilai-nilai dasar kemanusiaan yang berakar dari Pancasila yang masih terbatas pada pemahaman nilai dalam tataran konseptual, belum sampai mewujud menjadi nilai aktual yang menyenangkan di lingkungan sekolah, keluarga, dan masyarakat.

Pendidikan kesetaraan merupakan pendidikan nonformal, akan tetapi dalam pencapaian kompetensinya tetap mengacu kepada kurikulum pendidikan formal. Terkait dengan kompetensi lulusan, mata pelajaran Pendidikan Pancasila dan Kewarganegaraan (PPKn) menurut Udin S Winataputra (2007:1.1) bertujuan untuk mengembangkan kecerdasan warganegara (civic intelegency), membina tanggungjawab warganegara (civic responsibility), dan mendorong partisipasi warganegara (civic participation). 
Pengembangan kurikulum Pendidikan Pancasila dan Kewarganegaraan (PPKn) di pendidikan non formal berupaya menjadikan mata pelajaran yang mampu memberikan kontribusi dan solusi terhadap krisis multidimensional. Misi mata pelajaran Pendidikan Pancasila dan Kewarganegaraan (PPKn) adalah mengembangkan keadaban Pancasila yang mampu membudayakan dan memberdayakan peserta didik menjadi warganegara yang cerdas dan baik serta menjadi pemimpin bangsa dan negara Indonesia di masa depan yang amanah, jujur, cerdas, dan bertanggungjawab.

Selain itu, dalam konteks kehidupan global, mata pelajaran Pendidikan Pancasila dan Kewarganegaraan (PPKn) juga membekali warga belajar untuk hidup sebagai warga dunia (global citizenship) dengan nilai dan moral Pancasila sesuai dinamika kehidupan abad XXI (Kontekstualisasi Kurikulum 2013 Pendidikan Kesetaraan program paket A Setara SD/MI, Mata Pelajaran Pendidikan Pancasila dan Kewarganegaraan (PPKn), Kementerian Pendidikan dan Kebudayaan, 2017). Oleh karena itu, substansi dan pembelajaran Pendidikan Pancasila dan Kewarganegaraan (PPKn) diorientasikan pada visi dan keterampilan abad XXI sebagaimana telah menjadi komitmen global.

Pendidikan Kewarganegaraan dimaksudkan untuk membentuk Peserta Didik menjadi manusia yang memiliki rasa kebangsaan dan cinta tanah air dalam konteks nilai dan moral Pancasila, kesadaran berkonstitusi Undang - Undang Dasar Negara Republik Indonesia Tahun 1945, nilai dan semangat Bhinneka Tunggal Ika, serta komitmen Negara Kesatuan Republik Indonesia (Pasal $77 \mathrm{~J}$ ayat (1) huruf b Peraturan Pemerintah Nomor 32 Tahun 2013 yang telah dirubah dengan Peraturan Pemerintah Nomor 13 Tahun 2015 tentang Standar Nasional Pendidikan).

Secara khusus tujuan Pendidikan Pancasila dan kewarganegaraan (PPKn) yangberisikan keseluruhan dimensi tersebut bertujuan agar peserta didik mampu:

1. Menampilkan karakter yang mencerminkan penghayatan, pemahaman, dan pengamalan nilai dan moral Pancasila secara personal dan sosial. 2) memiliki komitmen konstitusional yang ditopang oleh sikap positif dan pemahaman utuh tentang Undang Undang Dasar Negara Republik Indonesia Tahun 1945.3) Berpikir secara kritis, rasional, dan kreatif serta memiliki semangat kebangsaan serta cinta tanah air yang dijiwai oleh nilai- nilai Pancasila, Undang Undang Dasar Negara Republik Indonesia Tahun 1945, semangat Bhinneka Tunggal Ika, dan komitmen Negara Kesatuan Republik Indonesia. 4) Berpartisipasi secara aktif, cerdas, dan bertanggung jawab sebagai anggota masyarakat, tunas bangsa, dan warga negara sesuai dengan harkat dan martabatnya sebagai makhluk ciptaan Tuhan Yang Maha Esa yang hidup bersama dalam berbagai tatanan sosial budaya (Peraturan Pemerintah Nomor 32 Tahun 2013 yang telah dirubah dengan Peraturan Pemerintah Nomor 13 Tahun 2015 tentang Standar Nasional Pendidikan). 
Mata pelajaran Pendidikan Pancasila dan Kewarganegaraan (PPKn) pada pendidikan kesetaraan memiliki ruang lingkup dengan aspek sebagai berikut:

1.) Pancasila, sebagai dasar negara, ideologi, dan pandangan hidup bangsa. 2) Undang Undang Dasar Republik Indonesia Tahun 1945 sebagai hukum dasar tertulis yang menjadi landasan konstitusional kehidupan bermasyarakat, berbangsa, dan bernegara. 3) Negara Kesatuan Republik Indonesia, sebagai kesepakatan final bentuk Negara Republik Indonesia. 4) Bhinneka Tunggal Ika, sebagai wujud filosofi kesatuan yang melandasi dan mewarnai keberagaman kehidupan bermasyarakat, berbangsa, dan bernegara (Peraturan Pemerintah Nomor 32 Tahun 2013 yang telah dirubah dengan Peraturan Pemerintah Nomor 13 Tahun 2015 tentang Standar Nasional Pendidikan).

Pendidikan Pancasila dan Kewarganegaraan (PPKn) sesuai dengan paradigma barunya sebagai pendidikan demokrasi bersifat multidimensional. Hal ini terlihat pada:

1) Pandangan yang pluralistik-uniter (bermacam- macam, tetapi menyatu dalam pengertian Bhinneka Tunggal lka. 2) Sikap dalam menempatkan individu, negara, dan masyarakat global secara harmonis. 3) Tujuan yang diarahkan pada semua dimensi kecerdasan (spiritual, rasional, emosional, dan sosial). 4) Konteksyang menghasilkan pengalaman belajar yang terbuka, fleksibel atau luwes, dan bervariasi merujuk kepada dimensi tujuannya (Udin $S$ Winataputra,2007: 1.1).

Dalam hal ini, Pendidikan Pancasila dan Kewarganegaraan (PPKn) dikelompokkan ke dalam mata pelajaran kewarganegaraan dan kepribadian yang bertujuan untuk peningkatan kesadaran dan wawasan peserta didik akan status, hak, dan kewajibannya dalam kehidupan bermasyarakat, berbangsa, dan bernegara, serta peningkatan kualitas dirinya sebagai manusia.

\section{METODE PENELITIAN}

Penelitian ini dilakukan dengan mengunakan penelitian dan pengembangan. Sugiyono (2013:407) mengatakan "Metode penelitian dan pengembangan adalah metode penelitian yang digunakan untuk menghasilkan produk tertentu dan menguji keektifan produk tersebut".

Sebelum membuat desain pengembangan model, tim pengembang model yang merupakan pamong belajar pada BP PAUD dan Dikmas Aceh telah melihat fenomena terkait bahan ajar pada program kesetaraan Paket A yang masih belum efektif digunakan. Terkait Metode pengumpulan data yang digunakan dalam penelitian pengembangan model penggunaan modul pada PKBM adalah observasi, kuesioner, dan wawancara. 
Pengembangan model dilakukan melalui empat tahapan pelaksanaan, yaitu(1) studi ekplorasi, (2) perumusan model, (3) ujicoba model, revisi dan analisis, dan (4) validasi model dan penerapan.

Waktu pelaksanaan, pengembangan model disesuaikan dengan Satuan Kerja tahun anggaran 2018, Balai Pengembangan Pendidikan Anak Usia Dini dan Pendidikan Masyarakat yang telah ditetapkan oleh Direktorat Jenderal Pendidikan Anak Usia Dini dan Pendidikan Masyarakat Kementerian Pendidikan dan Kebudayaan Republik Indonesia:

Lokasi pelaksanaan pengembangan model direncanakan di PKBM yang ada di Aceh Besar. Pemilihan tersebut dikarenakan beberapa alasan, yaitu (1) adanya kesediaan satuan pendidikan untuk menjadi tempat implementasi pengembangan model, (2) Adanya program pendidikan kesetaraan Paket A, dan (3) tersedianya sarana dan prasarana pendukung untuk pelaksanaan pengembangan model.

Data yang telah dikumpulkan dalam penelitian dan pengembangan model ini dianalisis dengan menggunakan metode deskriptif kualitatif.Data dianalisis dengan menggunakan kata-kata yang logis dan jelas sehingga menghasilkan sebuah narasi yang mudah dipahami. Analisis data dilakukan dalam tiga tahapan, yaitu:

1) Reduksi data dilakukan untuk kegiatan merangkum, memilih halhal yang pokok, 2). Penyajian Data (Data Display) Data disajikan dengan mengorganisasikan data hasil reduksi dalam bentuk deskriptif. 3).penarikan kesimpulan dan verifikasi.Pada tahap ini, peneliti melakukan penarikan kesimpulan penelitian berdasarkan pada hasil reduksi dan penyajian data.Langkah selanjutnya, peneliti menverifikasi data guna mendapatkan kebenaran dan kesesuaian data.Pengujian data dilakukan dengan menghubungkan data hasil penelitian dengan teori yang relevan.

Populasi dan target dalam penelitian ini adalah seluruh peserta didik kelas VI di PKBM Putri Gina Desa Tanjung Selamat Kecamatan Darussalam Kabupaten Aceh Besar. Populasi terjangkau dalam penelitian ini adalah peserta didik kelas VI di PKBM Putri Ginayang terdiri dari satu kelas dan jumlah warga belajar 15 orang. Tehnik dalam pengambilan sampel dalam penelitian ini adalah purposive sampling yaitu pengambilan sampel secara sengaja sesuai dengan pesyaratan komposisi anggota sampel berdasarkan jenis pelakuan.

\section{HASIL PENELITIAN DAN PEMBAHASAN}

Pada PKBM ini setelah dilaksanakannya uji opersional modul secara mandiri diperoleh beberapa hasil pengujian yaitu untuk penilaian kelayakan aspek materi sudah sangat baik, tetapi masih ada beberapa materi yang harus ditambahkan.Catatan untuk modul 1 yaitu satu nusa satu bangsa dikatakan bahwa bahasa yang digunakan pada modul tersebut masih ada yang tidak sesuai dengan warga belajar paket $A$, 
sehingga untuk pembelajaran secara mandiri harus lebih disederhanakan kembali kalimatnya.Kemudian untuk penugasan dikatakan bahwa warga belajar sedikit sulit untuk melakukan pengamatan terhadap warga belajar karena keterbatasan kemampuan.

Selanjutnya untuk penilaian kelayakan aspek materi sudah baik, dari aspek kebahasaan masih ada beberapa materi yang bahasanya masih tinggi.Penilaian kelayakan aspek penyajian sudah baik dan penilaian secara keseluruhan sudah baik hanya pada bahasa yang digunakan masih sedikit tinggi.

Untuk modul 2 dengan judul Pancasila dalam kehidupanku mendapat masukan bahwa muatan materi lebih diringkas karena kefektifan waktu pada warga belajar.Masih kurangnya latihan mandiri yang berkaitan dengan lingkungan sekitar.Selanjutnya untuk penilaian kelayakan aspek materi mendapat masukan untuk diselaraskan antara materi dan judul, serta contoh kegiatan yang masih kurang, dari aspek kebahasaan masih ada beberapa materi yang bahasanya sudah baik. Penilaian kelayakan aspek penyajian masih ada beberapa keruntutan penyajian yang masih kurang serta kurangnya soal yang berkaitan dengan mengidentifikasi.

Catatan untuk modul 3 yaitu hak dan kewajibanku dikatakan bahwa bahasa yang digunakan pada modul tersebut masih ada yang tidak sesuai dengan warga belajar paket $A$, sehingga untuk pembelajaran secara mandiri harus lebih disederhanakan kembali kalimatnya.Kemudian untuk penugasan dikatakan bahwa warga belajar sedikit sulit untuk melakukan pengamatan terhadap warga belajar karena keterbatasan kemampuan.

Selanjutnya untuk penilaian kelayakan aspek materi sudah baik, dari aspek kebahasaan masih ada beberapa materi yang bahasanya masih tinggi.Penilaian kelayakan aspek penyajian sudah baik dan penilaian secara keseluruhan sudah baik hanya pada bahasa yang digunakan masih sedikit tinggi.

Modul ke empat yaitu Warna warni bangsaku sudah bagus hanya pada gambar yang perlu diberi keterangan gambar untuk memudahkan warga belajar.Selanjutnya untuk penilaian kelayakan aspek materi sudah baik, dari aspek kebahasaan sudah baik.Penilaian kelayakan aspek penyajian sudah baik dan penilaian secara keseluruhan sudah baik. Hasil penelitian ini merupakan hasil dari pembagian angket.

Selanjutnya tim pengembang juga melakukan wawancara kepada tutor dan warga belajar terkait bahan ajar yang digunakan sebelumnya bahwa belum ada bahan ajar yang resmi, hanya mengunduh dari internet atau mengambil dari buku formal. Untuk metode pembelajaran yang digunakan, sebagian besar tutor masih menggunakan metode ceramah dan tanya jawab. Kemudian untuk judul modul jangan terlalu panjang.Untuk penugasan pada modul ini, warga belajar masih menanyakan pada tutor tapi untuk sebagian penugasan sudah melakukan secara mandiri. 
Pembelajaran modul pada PKBM ini dilaksanakan secara tatap muka diperoleh beberapa hasil pengujian yaitu untuk penilaian kelayakan aspek materi sudah sangat baik, tetapi masih ada beberapa materi yang harus ditambahkan. Catatan untuk modul 1 yaitu Pancasila perisaiku dikatakan bahwa bahasa yang digunakan pada modul tersebut masih ada yang tidak sesuai dengan warga belajar paket $A$, sehingga untuk pembelajaran secara mandiri harus lebih disederhanakan kembali kalimatnya.Kemudian untuk penugasan dikatakan bahwa warga belajar sedikit sulit untuk melakukan pengamatan terhadap warga belajar karena keterbatasan kemampuan.

Selanjutnya untuk penilaian kelayakan aspek materi sudah baik, dari aspek kebahasaan masih ada beberapa materi yang bahasanya masih tinggi.Penilaian kelayakan aspek penyajian sudah baik dan penilaian secara keseluruhan sudah baik hanya pada bahasa yang digunakan masih sedikit tinggi.

Untuk modul 2 dengan judul Pancasila dalam kehidupanku mendapat masukan bahwa muatan materi lebih diringkas karena kefektifan waktu pada warga belajar.Masih kurangnya latihan mandiri yang berkaitan dengan lingkungan sekitar.Selanjutnya untuk penilaian kelayakan aspek materi mendapat masukan untuk diselaraskan antara materi dan judul, serta contoh kegiatan yang masih kurang, dari aspek kebahasaan masih ada beberapa materi yang bahasanya sudah baik.Penilaian kelayakan aspek penyajian masih ada beberapa keruntutan penyajian yang masih kurang serta kurangnya soal yang berkaitan dengan mengidentifikasi.

Catatan untuk modul 3 yaitu hak dan kewajibanku dikatakan bahwa bahasa yang digunakan pada modul tersebut masih ada yang tidak sesuai dengan warga belajar paket $A$, harus lebih disederhanakan kembali kalimatnya.Kemudian untuk penugasan dikatakan bahwa warga belajar sedikit sulit untuk melakukan pengamatan terhadap warga belajar karena keterbatasan kemampuan serta pemberian tugas yang terlalu banyak sehingga warga belajar banyak meminta bantuan pada tutor.

Selanjutnya untuk penilaian kelayakan aspek materi sudah baik, dari aspek kebahasaan masih ada beberapa materi yang bahasanya masih tinggi.Penilaian kelayakan aspek penyajian sudah baik dan penilaian secara keseluruhan sudah baik hanya pada bahasa yang digunakan masih sedikit tinggi.

Modul ke empat yaitu Warna warni bangsaku sudah bagus hanya pada gambar yang perlu diberi keterangan gambar untuk memudahkan warga belajar serta bahasa yang digunakan lebih di sederhanakan lagi.Selanjutnya untuk penilaian kelayakan aspek materi sudah baik, dari aspek kebahasaan sudah baik.Penilaian kelayakan aspek penyajian sudah baik dan penilaian secara keseluruhan sudah baik. Hasil penelitian ini merupakan hasil dari pembagian angket.

Selanjutnya tim pengembang juga melakukan wawancara kepada tutor dan warga belajar terkait bahan ajar yang digunakan sebelumnya 
bahwa belum ada bahan ajar yang resmi, hanya mengunduh dari internet atau mengambil dari buku formal. Untuk metode pembelajaran yang digunakan, sebagian besar tutor masih menggunakan metode ceramah dan tanya jawab kemudian untuk pertanyaan ada beberapa pertanyaan yang masih sulit untuk warga belajar Paket $A$. Selain itu warga belajar juga telah menyelesaikan berbagai penugasan pada modul. Hasil penugasan tersebut terdapat pada lampiran.

\section{Pretest dan Post test}

Selain melaksanakan penelitian melalui pengamatan, angket dan wawancara, pengembang memberikan pretest dan post test kepada warga belajar.Untuk melihat pengaruh hasil belajar sebelum dan sesudah menggunakan modul.Berikut hasildari PKBM Putri Ginauji operasional modul pendidikan kesetaraan Mata Pelajaran PPKn Paket A setara $\mathrm{SD} / \mathrm{MI}$.

Tabel 2. Data Nilai Pre Test dan Post Test Pusat Kegiatan Belajar Masyarakat (PKBM) Putri Gina

\begin{tabular}{cccc}
\hline No & Responden & Nilai Pretest & Post test \\
\hline 1 & Responden 1 & 80 & 92 \\
2 & Responden 2 & 88 & 76 \\
3 & Responden 3 & 72 & 64 \\
4 & Responden 4 & 72 & 96 \\
5 & Responden 5 & 84 & 84 \\
6 & Responden 6 & 80 & 92 \\
7 & Responden 7 & 88 & 96 \\
8 & Responden 8 & 76 & 92 \\
9 & Responden 9 & 76 & 80 \\
10 & Responden 10 & 84 & 90 \\
11 & Responden 11 & 68 & 75 \\
12 & Responden 12 & 80 & 89 \\
13 & Responden 13 & 64 & 70 \\
14 & Responden 14 & 70 & 93 \\
15 & Responden 15 & 60 & 76
\end{tabular}

\section{KESIMPULAN}

Dari uji coba yang dilakukan tim pengembang, dapat ditarik kesimpulan terkait pengembangan model penyusunan modul pendidikan kesetaraan Mata Pelajaran PPKn Paket A setara SD/MI, yaitu: 1) Setelah melaksanakan studi pendahuluan pada beberapa PKBM yang melaksanakan program kesetaraan paket $A$, terdapat beberapa permasalahan terkait kegiatan belajar mengajar. Dikatakan oleh tutor bahwa untuk silabus, mereka mengacu dari silabus pendidikan formal. Kemudian untuk bahan ajar, para tutor mengunduh pada internet atau 
melihat buku formal. 2) Bahan ajar yang efektif pada pembelajaran paket adalah dengan menggunakan modul. Modul ini mengacu pada kurikulum 2013 dan silabus yang telah disusun oleh direktorat. Modul tersebut disusun oleh tim penulis modul dan kemudian dilakukan pengujian secara substansi dan juga pengujian di lapangan. Setelah dilakanakan pengujian, pembelajaran dengan menggunakan modul ini memiliki keefektifan dalam proses pembelajaran. Hal ini juga didukung dengan penyusunan modul yang bersifat mandiri dan konstekstual sehingga memudahkan warga belajar paket yang memiliki keterbatas waktu untuk mengikuti kegiatan belajar mengajar dapat tetap mengikuti pembelajaran berbasis modul secara mandiri.

\section{DAFTAR PUSTAKA}

Abdi, Supriyanto, dkk. (2008). Potret Pemenuhan Hak Atas Pendidikan Dan Pemenuhan Di Era Otonomi Daerah. Yogyakarta: PUSHAM UI.

Ali Imron. (n.d.). Belajar dan Pembelajaran. Jakarta: PT Pustaka Jaya.

Ananda Fitria. (n.d.). Pengaruh Lingkungan Sekolah, Peran Guru dalam Proses Pembelajaran, di akses.

Bagong, Suyanto. (2010). Metode Penelitian Sosial. Jakarta: Prenada Media Group.

Buckingham. (2012). Buku Telaah Buku Teks. Bandung: Penerbit Angkasa.

Buku Teks Dalam Pembelajaran Geografi Di Kota Semarang. (2007). Jurnal Geografi. https://doi.org/10.15294/jg.v4i2.106

Dalyono, M. (2009). Psikologi Pendidikan dan Pembelajaran Kompetensi. Jakarta: Renika Cipta.

Depdiknas. (2004). Pedoman Penulisan Buku Pelajaran Penjelasan Standar Mutu Buku Pembelajaran Bahasa dan Sastra. Jakarta: Depdiknas.

S. Sadirman Arif. (2011). Media Pendidikan: Pengertian, Pengembangan dan Pemanfaatannya . Jakarta : Raja Grafindo Persada.

Suprihatin, Siti. (2015). "Upaya Guru Dalam Meningkatkan Motivasi Belajar Siswa."

Tilaar, H.A.R. (2002). Perubahan Sosial dan Pendidikan: Pengantar Pedagogik Transformatif untuk Indonesia. Jakarta: Grasindo 
Undang- Undang Nomor 20 Tahun 2003

Yusnadi. (2004). Perencanaan Program Pendidikan Luar Sekolah. Medan: Universitas Negeri Medan 